\title{
THE EFFECTS OF ALTERATIONS OF PLASMA SODIUM AND POTASSIUM CONCENTRATION ON ALDOSTERONE SECRETION *
}

\author{
By JAMES O. DAVIS, JOHN URQUHART, AND JAMES T. HIGGINS, JR., With the \\ SURGICAL ASSISTANCE OF ALFRED CASPER AND THE TECH NICAL ASSISTANCE OF \\ ELEANOR CAVANAUGH
}

\author{
(From the Section on Experimental Cardiovascular Disease, Laboratory of Kidney and Elec- \\ troly'te Metabolism, National Heart Institute, Bethesda, Md.)
}

(Submitted for publication June 18, 1962; accepted January 10, 1963)

Many studies have been conducted on the relation of electrolytes to the control of aldosterone secretion. It was reported by Luetscher and Axelrad (1) and confirmed by others (2-4) that a low $\mathrm{Na}$ intake augments the rate of urinary aldosterone excretion in normal man. Also, it has been clearly established that chronic $\mathrm{Na}$ depletion increases aldosterone secretion in sheep $(5,6), \operatorname{dogs}(7,8)$, and rats (9). On the other hand, the relation of $\mathrm{K}$ intake to aldosterone production has never been settled. Several investigators $(2,3,10)$ have reported that $\mathrm{K}$ loading leads to hyperaldosteronuria; the response was observed only in the presence of a low $\mathrm{Na}$ intake or was greater with a reduced intake of salt. In contrast, Hernando and associates (4) failed to find an increase in urinary aldosterone output during $\mathrm{K}$ loading even in the presence of a superimposed low $\mathrm{Na}$ intake.

The influence of hyperkalemia and of hyponatremia has also been a controversial issue. Laragh and Stoerk (10) were first to report that a high plasma $\mathrm{K}$ concentration increases aldosterone secretion. Later, Moran. Rosenberg, and Zimmerman (11) presented data which suggested that intravenous infusion of $\mathrm{KCl}$ into intact dogs increased aldosterone secretion, but Gann, Cruz, Casper, and Bartter (12) were unable to confirm this finding. Denton. Goding, and Wright (5) provided evidence that a low $\mathrm{Na}$ and high $\mathrm{K}$ concentration in plasma perfusing an isolated adrenal stimulates aldosterone production in sheep; also. some of their more recent findings (6) suggest that this directional alteration in either ion alone augments aldosterone secretion.

\footnotetext{
* Preliminary report was made at the meeting of the Federation of American Societies for Experimental Biology, April, 1962.
}

The present observations were undertaken to determine the separate influences of 1) a decrease in plasma $\mathrm{Na}$ concentration and 2) an elevation in the plasma $\mathrm{K}$ level on aldosterone secretion. As emphasized previously $(13,14)$, it is frequently important for acute studies in laparotomized dogs to be conducted in hypophysectomized animals because of the influence of ACTH which is present in increased amounts in stressed animals. Studies were first conducted on the effects of intravenous infusion of a $\mathrm{K}$ salt on aldosterone secretion in hypophysectomized dogs. Subsequently, the influence of acute bilateral nephrectomy on the hypersecretion of aldosterone induced by hyperkalemia was determined. The possible direct effect of either a low plasma $\mathrm{Na}$ or a high plasma $\mathrm{K}$ concentration on the adrenal cortex was examined by producing local alterations in these ions in arterial blood perfusing isolated adrenals. Finally, the physiological significance of alterations in $\mathrm{K}$ intake on aldosterone production was investigated by studying the response to a high $\mathrm{K}$ intake. The plasma $\mathrm{K}$ concentration and the rate of urinary aldosterone excretion were observed for several hours following the daily meal during which a progressive elevation in the plasma $\mathrm{K}$ concentration occurred during the high $\mathrm{K}$ diet.

\section{MATERIALS AND METHODS}

Intraz'enous infusion of potassium salts. The experiments were performed in mongrel dogs which were hypophysectomized by the oral approach (15) 2 hours before the study. After control observations, $\mathrm{KCl}$ or $\mathrm{K}_{2} \mathrm{SO}_{+}$was infused intravenously in a concentration of $\mathrm{K}$ of $1 \mathrm{mEq}$ per $\mathrm{ml}$ in normal saline at rates of 0.55 to $1.14 \mathrm{ml}$ per minute. Electrocardiograms were taken to provide an immediate index of the plasma $\mathrm{K}$ level while actual determinations were made of the concentrations 
of plasma $\mathrm{K}$ and of plasma $\mathrm{Na}$. Arterial blood pressure was measured continuously throughout the experiments by methods described earlier (16). Adrenal venous blood was collected by a technique previously reported (16) and the rates of secretion of aldosterone, corticosterone, and Porter-Silber chromogens were measured. After production of hyperkalemia, nephrectomy was performed and observations were made 30 minutes to 1 hour later; when necessary, an additional infusion of $\mathrm{K}$ was given to increase plasma $\mathrm{K}$ after nephrectomy.

Isolated adrenal preparation and procedure for perfusing adrenals with a high concentration of plasma $K$ or a low concentration of plasma $\mathrm{Na}$. Normal dogs were hypophysectomized, and the adrenals were isolated by the technique of Hilton and associates (17) ; during this procedure the kidneys were removed. The animals were given $200 \mathrm{mg}$ of cortisone acetate (one-half orally and one-half intramuscularly) immediately before hypophysectomy. The combined procedures of hypophysectomy and adrenal isolation required 4.0 to 4.5 hours. Blood was circulated through the isolated adrenals from the animal's right carotid artery and returned to the right external jugular vein. To obtain adrenal vein blood, venous flow to the external jugular vein was temporarily interrupted and blood was collected in a graduated tube.

To increase the concentration of $\mathrm{K}$ in arterial blood circulating through isolated adrenals, $\mathrm{KCl}$ or $\mathrm{K}_{2} \mathrm{SO}_{4}$ in normal saline in concentrations of $\mathrm{K}$ of 13 to $147 \mu \mathrm{Eq}$ per $\mathrm{ml}$ was injected into the arterial blood supplying the adrenal at a rate of $0.55 \mathrm{ml}$ per minute by a constant infusion pump. In most instances the concentrations of $\mathrm{K}$ ranged from 27 to $33 \mu \mathrm{Eq}$ per $\mathrm{ml}$. A low $\mathrm{Na}$ concentration was achieved in the adrenal perfusate by infusion of $5 \%$ glucose in water at rates of 0.55 to $1.50 \mathrm{ml}$ per minute. The infusion rate was varied in accordance with adrenal blood flow in an attempt to achieve plasma $\mathrm{Na}$ concentrations of 120 to $130 \mathrm{mEq}$ per L. As a control for this experiment, $5 \%$ glucose in normal saline was perfused through isolated adrenals at a rate of $0.98 \mathrm{ml}$ per minute. Arterial bood pressure was measured continuously in the segment of isolated aorta associated with the adrenals.

The effects of a high plasma $\mathrm{K}$ or a low plasma $\mathrm{Na}$ level on the rates of secretion of aldosterone and corticosterone were studed. After two groups of control observations on steroid secretion, the plasma concentrations of either $\mathrm{Na}$ or $\mathrm{K}$ were altered by infusion for 30 minutes and observations were made again. Plasma $\mathrm{Na}$ and $\mathrm{K}$ concentrations were measured in the adrenal venous effluent.

Influence of electrolyte intake on plasma $K$ concentration. The influence of dietary $\mathrm{K}$ on the plasma $\mathrm{K}$ concentration was studied in 10 dogs on a normal $\mathrm{Na}$ (60 $\mathrm{mEq}$ per day) and a high $\mathrm{K}(150 \mathrm{mEq}$ per day) intake, and in another $10 \mathrm{dogs}$ on a low $\mathrm{Na}$ ( 2 to $3 \mathrm{mEq}$ per day) and a high $\mathrm{K}$ ( $150 \mathrm{mEq}$ per day) intake. Blood was obtained in fasting animals at 8:30 to 9:00 a.m. The animals were fed the synthetic diet at 9:00 a.m., and blood was drawn for determination of the plasma $\mathrm{K}$ level at $1,3,5$, and 7 hours after feeding.
Effects of alterations in dietary $K$ on plasma $K$ concentration and urinary aldosterone cxcretion. The effects of a high $\mathrm{K}$ intake on plasma $\mathrm{K}$ and on urinary aldosterone excretion were studied in the presence of a normal and a low $\mathrm{Na}$ intake. Since the animals were fed only once daily, the high $\mathrm{K}$ diet was given as a large oral load; $\mathrm{KCl}$ was added to the diet. Urine was collected in jars surrounded by dry ice to freeze the urine immediately after excretion. The bladder was catheterized at 8:30 each morning, and a blood sample was obtained for analysis of $\mathrm{K}$. The dogs were fed a synthetic diet immediately.: Another blood sample was drawn at 1 to 2 p.m., and the bladder was catheterized at 5 p.m. and again the next morning at 8.30 a.m. Thus, $7 \frac{1}{2}-$ and $16 \frac{1}{2}-$ hour urine collections were obtained. Since the plasma K concentration reaches a maximum and begins to decline during the first $7 \frac{1}{2}$-hour collection period, measurements of aldosterone excretion were made on this part of the daily collection in an attempt to relate aldosterone production to the postprandial level of plasma $\mathrm{K}$. After studies on the $60 \mathrm{mEq}$ per day $\mathrm{Na}$ and $18 \mathrm{mEq}$ per day $\mathrm{K}$ diet for approximately 1 week, the $\mathrm{K}$ intake was increased to $150 \mathrm{mEq}$ per day, and aldosterone excretion was measured again. Finally, the effects of a low $\mathrm{Na}$ ( 4 to $5 \mathrm{mEq}$ per day) and a high $\mathrm{K}$ ( $150 \mathrm{mEq}$ per day) diet were studied.

Chemical determinations. The concentrations of aldosterone and corticosterone in adrenal vein plasma were determined by the double isotope derivative technique of Kliman and Peterson (18). The concentration of aldosterone in urine was determined after acidifying the urine to $\mathrm{pH} 1$ by use of the Kliman and Peterson technique (18). In an earlier study (19), it was found that the dog urine samples for aldosterone were not always radiochemically pure after three chromatographies as reported by Kliman and Peterson (18) for human urine. Consequently, a fourth chromatography was added (19) to the procedure for measuring urinary aldosterone. In the present experiments, eight urine samples obtained from three of the four dogs during the high $\mathrm{K}$ diet were subjected to a fifth chromatography: the values for aldosterone were unchanged. Porter-Silber chromogens were measured in adrenal vein plasma by a modification of the procedure of Peterson, Karrer, and Guerra (20). The concentrations of plasma, urinary and fecal $\mathrm{Na}$ and $\mathrm{K}$ were determined by flame photometry.

\section{RESULTS}

Effects of intravenous infusion of potassium salts on steroid secretion in hypophysectomized dogs. The experimental design and the results in a typical experiment (experiment 6 of Table I) are presented in Figure 1. Infusion of $\mathrm{KCl}$ resulted in a striking increase in aldosterone secretion from a mean control value for the group of .002 to $.031 \mu \mathrm{g}$ per minute $(\mathrm{n}=7 ; \mathrm{p}<.01)$ (Table I). This increase in aldosterone output was associated with an elevation in plasma $\mathrm{K}$ con- 


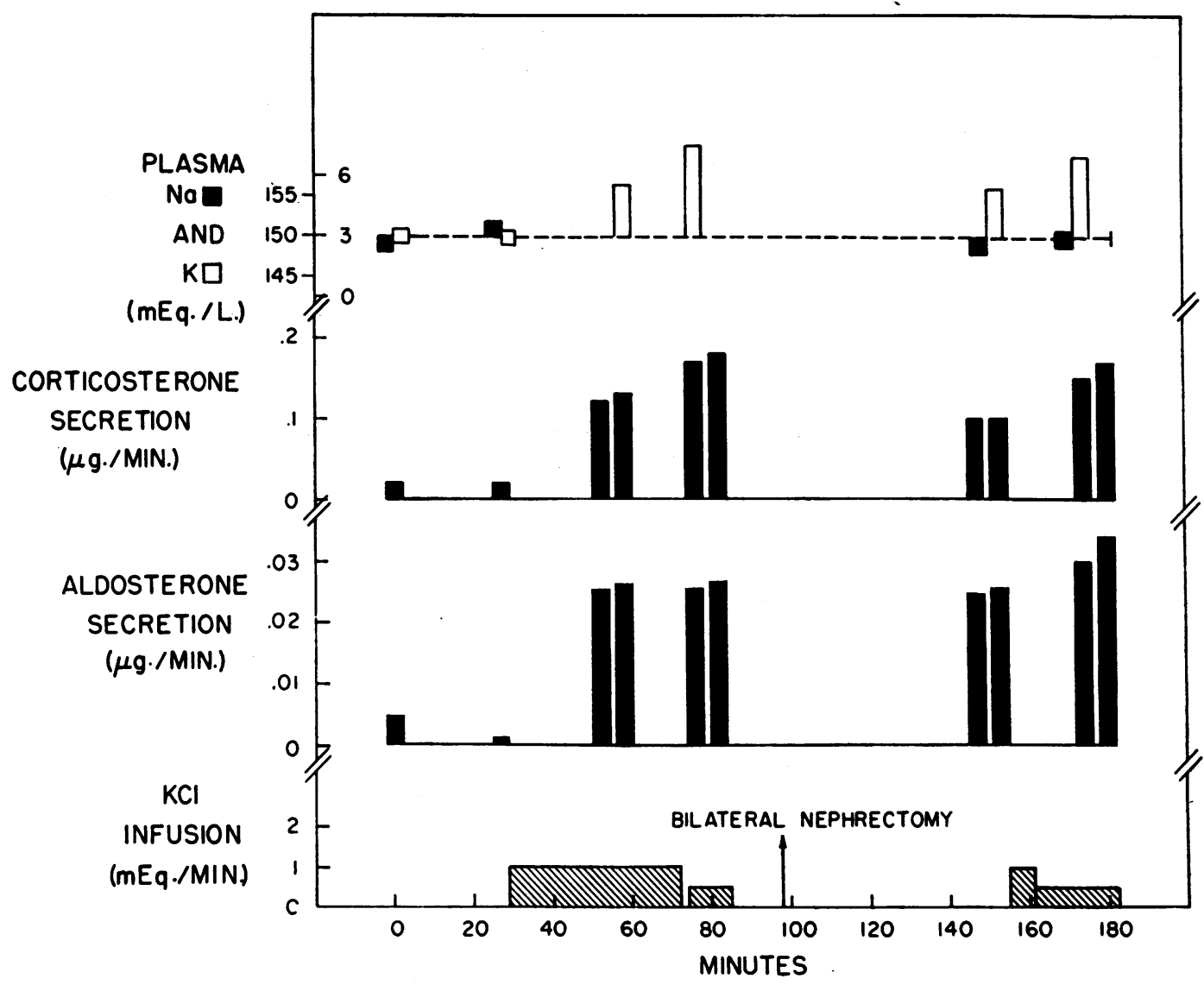

Fig. 1. Results of a typical experiment during the PERIPHeral intravenous infusion of $\mathrm{KCl}$ INTO A HYPOPHYSECTOMIZED DOG (Experiment 6 of Table I).

centration from a mean value of 3.3 to $6.3 \mathrm{mEq}$ per $\mathrm{L}(\mathrm{p}<.01)$. An increase in aldosterone secretion occurred with increments in plasma $\mathrm{K}$ concentration as small as 1.3 to $1.6 \mathrm{mEq}$ per $\mathrm{L}$ (dogs $1,5$, and 7$)$. The highest secretion rates of aldosterone were accompanied by the highest levels of plasma $\mathrm{K}$ in $\operatorname{dogs} 1,2,3$, and 5 . The concentration of plasma $\mathrm{Na}$ was unchanged by the infusion of $\mathrm{KCl}$. The average value for the plasma $\mathrm{Na}$ level during the control period was $154 \mathrm{mEq}$ per $\mathrm{L}$; during the infusion of $\mathrm{KCl}$ a value of $155 \mathrm{mEq}$ per $\mathrm{L}$ of plasma was obtained. Also, adrenal blood flow was essentially the same during the control period and during $\mathrm{KCl}$ infusion.

Corticosterone secretion was very low during the control period, a finding which reflects the adequacy of hypophysectomy. During infusion of $\mathrm{KCl}$, corticosterone output was increased in every dog (Table I). The response varied considerably among the animals; the greatest increments in cor- ticosterone production occurred in experiments 1 and 2 , in which a marked response in aldosterone output was also observed. In general (dogs 3 to $7)$, the increment in corticosterone secretion was only to a level of approximately $10 \%$ of that observed in anesthetized, stressed, normal dogs (2.34 $\pm \mathrm{SD}$ of $.84 \mu \mathrm{g}$ per minute) (13). In dogs 1 and 2 , however, the rates of corticosterone secretion in response to $\mathrm{K}$ reached levels of approximately $50 \%$ of the value for anesthetized, stressed, normal dogs.

Porter-Silber chromogen secretion increased in only 2 of the 7 animals (experiments 1 and 2 of Table I). In one of these dogs, Porter-Silber chromogen output increased from .25 to $2.50 \mu \mathrm{g}$ per minute while plasma $\mathrm{K}$ increased from 3.7 to $7.2 \mathrm{mEq}$ per L. In the other animal, Porter-Silber chromogen production increased from .23 to $2.70 \mu \mathrm{g}$ per minute in association with an increment in plasma $\mathrm{K}$ from 3.6 to $7.5 \mathrm{mEq}$ per $\mathrm{L}$. 
To determine whether another $\mathrm{K}$ salt would increase aldosterone secretion and, thus, to provide evidence for an effect of the $\mathrm{K}$ ion per se, $\mathrm{K}_{2} \mathrm{SO}_{4}$ was infused intravenously into six hypophysectomized dogs. Aldosterone secretion increased in all animals (Table $\mathrm{I}$ ), and the average change for the group was highly significant $(p<.01)$. Corticosterone secretion increased in five of the six animals.

In six of the hypophysectomized dogs given the
$\mathrm{KCl}$ infusion, the effects of subsequent nephrectomy were studied (Table I and Figure 1). The results were variable. In dogs 2,3 , and 6 , the rates of aldosterone secretion remained elevated or increased further during the maintenance of hyperkalemia after nephrectomy. In dogs 3 and 6 , corticosterone production also remained elevated after nephrectomy, whereas in dog 2 corticosterone output fell despite a persistently elevated rate of

TABLE I

Effects of intravenous infusion of potassium chloride or potassium sulfate in hypophysectomized dogs

\begin{tabular}{|c|c|c|c|c|c|c|c|c|}
\hline \multirow[b]{2}{*}{ Experiment } & & \multicolumn{2}{|c|}{ Control periods } & \multicolumn{3}{|c|}{ During potassium infusion } & \multicolumn{2}{|c|}{ After nephrectomy } \\
\hline & & 1 & 2 & 1 & 2 & 3 & 1 & 2 \\
\hline \multicolumn{9}{|c|}{ Potassium chloride infusion } \\
\hline 1 & $\begin{array}{l}\text { Aldosterone* } \\
\text { Corticosterone } \\
\text { Plasma K }\end{array}$ & $\begin{array}{l}.005 \\
.14 \\
3.6\end{array}$ & $\begin{array}{l}.007 \\
.13\end{array}$ & $\begin{array}{l}.053 \\
1.16 \\
7.5\end{array}$ & $\begin{array}{l}.035 \\
.98 \\
5.5\end{array}$ & $\begin{array}{l}.036 \\
.76 \\
5.0\end{array}$ & & \\
\hline 2 & $\begin{array}{l}\text { Aldosterone } \\
\text { Corticosterone } \\
\text { Plasma K }\end{array}$ & $\begin{array}{l}.001 \\
.02\end{array}$ & $\begin{array}{l}.002 \\
.04 \\
3.7\end{array}$ & $\begin{array}{l}.024 \\
.64 \\
7.2\end{array}$ & $\begin{array}{l}.030 \\
.77 \\
8.5\end{array}$ & $\begin{array}{l}.024 \\
1.04 \\
7.5\end{array}$ & $\begin{array}{l}.032 \\
.59 \\
9.2\end{array}$ & $\begin{array}{l}.020 \\
.23 \\
10.0\end{array}$ \\
\hline 3 & $\begin{array}{l}\text { Aldosterone } \\
\text { Corticosterone } \\
\text { Plasma K }\end{array}$ & $\begin{array}{l}.000 \\
.03\end{array}$ & $\begin{array}{l}.007 \\
.03 \\
3.5\end{array}$ & $\begin{array}{l}.024 \\
.18 \\
7.5\end{array}$ & $\begin{array}{l}.026 \\
.27 \\
11.1\end{array}$ & & $\begin{array}{l}.041 \\
.13 \\
8.5\end{array}$ & $\begin{array}{l}.056 \\
.28 \\
10.0\end{array}$ \\
\hline 4 & $\begin{array}{l}\text { Aldosterone } \\
\text { Corticosterone } \\
\text { Plasma K }\end{array}$ & $\begin{array}{l}.005 \\
.07\end{array}$ & $\begin{array}{l}.002 \\
.05 \\
3.1\end{array}$ & $\begin{array}{l}.039 \\
.14 \\
5.4\end{array}$ & $\begin{array}{l}.044 \\
.15\end{array}$ & $\begin{array}{l}.036 \\
.12 \\
7.8\end{array}$ & $\begin{array}{l}.017 \\
.03\end{array}$ & $\begin{array}{l}.015 \\
.03 \\
6.9\end{array}$ \\
\hline 5 & $\begin{array}{l}\text { Aldosterone } \\
\text { Corticosterone } \\
\text { Plasma K }\end{array}$ & $\begin{array}{l}.002 \\
.19\end{array}$ & $\begin{array}{l}.003 \\
.18 \\
3.1\end{array}$ & $\begin{array}{l}.014 \\
.27 \\
4.4\end{array}$ & $\begin{array}{l}.016 \\
.30 \\
5.0\end{array}$ & $\begin{array}{l}.040 \\
.64 \\
7.5\end{array}$ & $\begin{array}{l}.008 \\
.11\end{array}$ & $\begin{array}{l}.014 \\
.14 \\
5.5\end{array}$ \\
\hline 6 & $\begin{array}{l}\text { Aldosterone } \\
\text { Corticosterone } \\
\text { Plasma K }\end{array}$ & $\begin{array}{l}.004 \\
.02 \\
2.8\end{array}$ & $\begin{array}{l}.001 \\
.02 \\
2.9\end{array}$ & $\begin{array}{l}.025 \\
.12\end{array}$ & $\begin{array}{l}.026 \\
5.13\end{array}$ & $\begin{array}{l}.025 \\
.17 \\
7.5\end{array}$ & $\begin{array}{l}.024 \\
.10 \\
5.7\end{array}$ & $\begin{array}{l}.032 \\
.16 \\
7.1\end{array}$ \\
\hline 7 & $\begin{array}{l}\text { Aldosterone } \\
\text { Corticosterone } \\
\text { Plasma K }\end{array}$ & $\begin{array}{l}.005 \\
.03 \\
3.4\end{array}$ & $\begin{array}{l}.002 \\
.04\end{array}$ & $\begin{array}{l}.028 \\
.21 \\
5.0\end{array}$ & $\begin{array}{l}.025 \\
.15 \\
6.8\end{array}$ & & $\begin{array}{l}.011 \\
.02 \\
5.8\end{array}$ & $\begin{array}{l}.010 \\
.05 \\
7.2\end{array}$ \\
\hline \multicolumn{9}{|c|}{ Potassium sulfate infusion } \\
\hline 1 & $\begin{array}{l}\text { Aldosterone } \\
\text { Corticosterone } \\
\text { Plasma K }\end{array}$ & $\begin{array}{l}.034 \\
.32 \\
4.5\end{array}$ & $\begin{array}{l}.042 \\
.61 \\
4.6\end{array}$ & $\begin{array}{l}.047 \\
1.05 \\
6.8\end{array}$ & $\begin{array}{l}.051 \\
1.06\end{array}$ & & & \\
\hline 2 & $\begin{array}{l}\text { Aldosterone } \\
\text { Corticosterone } \\
\text { Plasma K }\end{array}$ & $\begin{array}{l}.004 \\
.08 \\
3.6\end{array}$ & $\begin{array}{l}.003 \\
.09 \\
3.9\end{array}$ & $\begin{array}{l}.027 \\
.09\end{array}$ & $\begin{array}{l}.035 \\
.14 \\
5.8\end{array}$ & & & \\
\hline 3 & $\begin{array}{l}\text { Aldosterone } \\
\text { Corticosterone } \\
\text { Plasma K }\end{array}$ & $\begin{array}{l}.030 \\
.15 \\
4.1\end{array}$ & $\begin{array}{l}.030 \\
.17 \\
3.9\end{array}$ & $\begin{array}{l}.051 \\
.27 \\
7.5\end{array}$ & $\begin{array}{l}.052 \\
.28\end{array}$ & & & \\
\hline 4 & $\begin{array}{l}\text { Aldosterone } \\
\text { Corticosterone } \\
\text { Plasma K }\end{array}$ & $\begin{array}{l}.000 \\
.00 \\
3.3\end{array}$ & $\begin{array}{l}.000 \\
.05 \\
2.9\end{array}$ & $\begin{array}{l}.022 \\
.17 \\
5.3\end{array}$ & $\begin{array}{l}.031 \\
.20 \\
6.9\end{array}$ & & & \\
\hline 5 & $\begin{array}{l}\text { Aldosterone } \\
\text { Corticosterone } \\
\text { Plasma K }\end{array}$ & $\begin{array}{l}.001 \\
.02\end{array}$ & $\begin{array}{l}.002 \\
.02 \\
2.5\end{array}$ & $\begin{array}{l}.006 \\
.07 \\
4.9\end{array}$ & $\begin{array}{l}.007 \\
.09 \\
4.2\end{array}$ & & & \\
\hline 6 & $\begin{array}{l}\text { Aldosterone } \\
\text { Corticosterone } \\
\text { Plasma K }\end{array}$ & $\begin{array}{l}.000 \\
.02 \\
3.0\end{array}$ & $\begin{array}{l}.000 \\
.02 \\
3.5\end{array}$ & $\begin{array}{l}.013 \\
.13 \\
7.5\end{array}$ & $\begin{array}{l}.012 \\
.13 \\
8.9^{-13}\end{array}$ & & & \\
\hline
\end{tabular}

* The rates of aldosterone and corticosterone secretion are expressed in micrograms per minute. The plasma $\mathrm{K}$ concentration is expressed in milliequivalents per liter. 


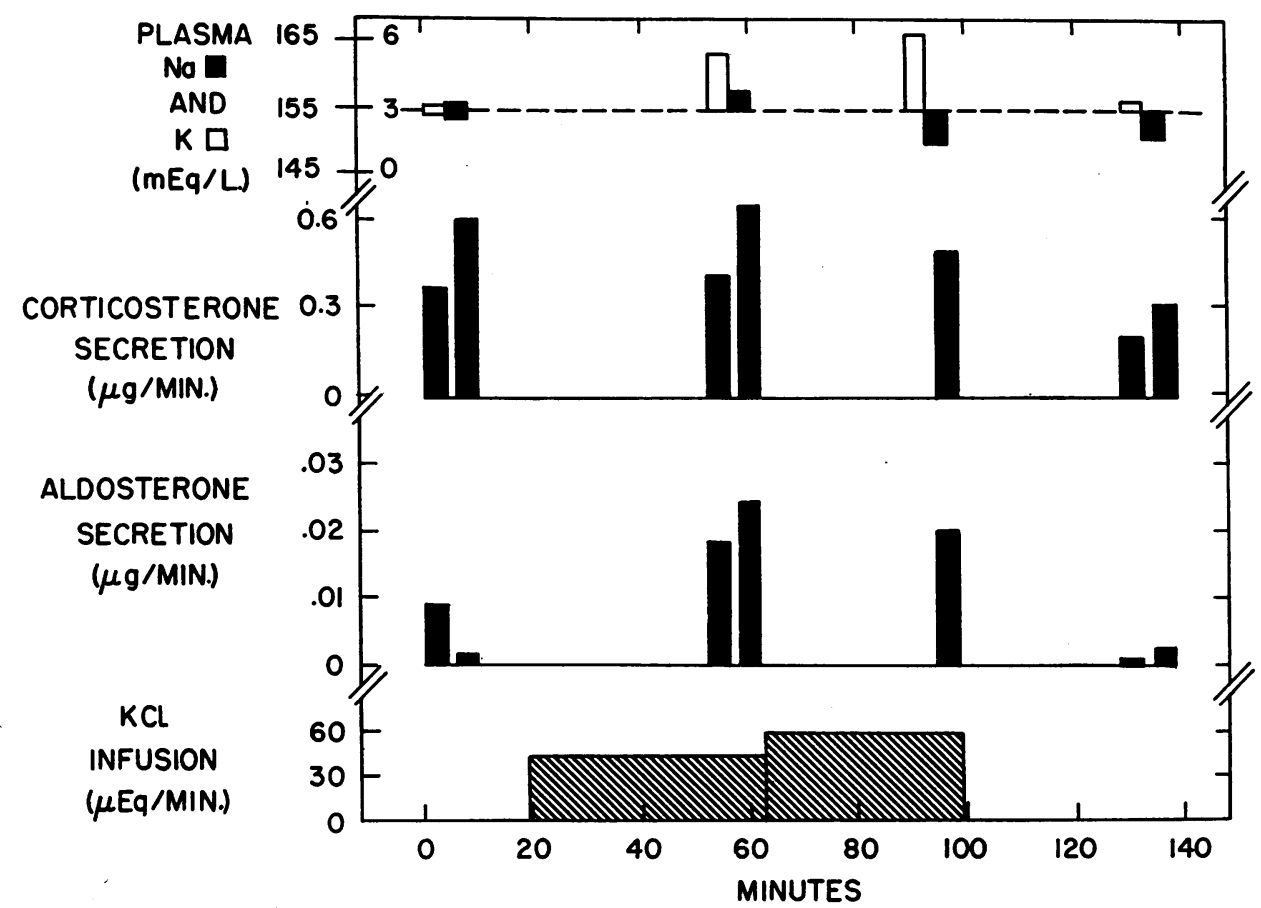

Fig. 2. Typical Results of INFusion of KCl into the arterial SUPPly OF ISOlated ADRENALS OF A HYPOPHYSECTOMIZED-NEPHRECTOMIZED DOG.

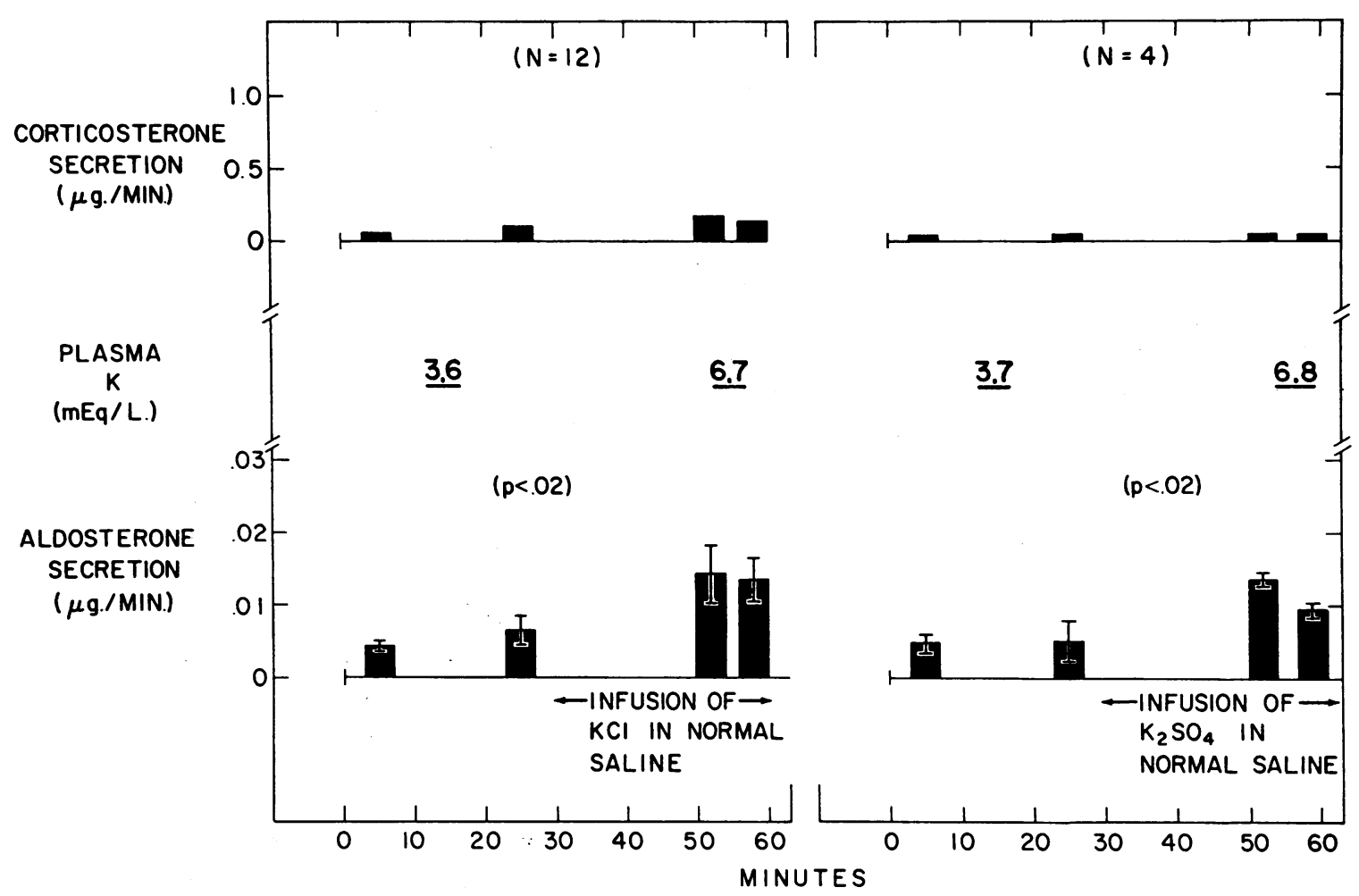

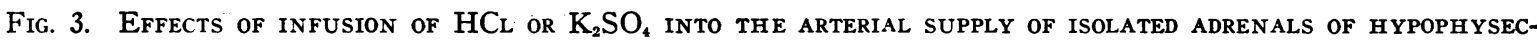
TOMIZED-NEPHRECTOMIZED DOGS. Mean values and standard errors are given for aldosterone secretion. 


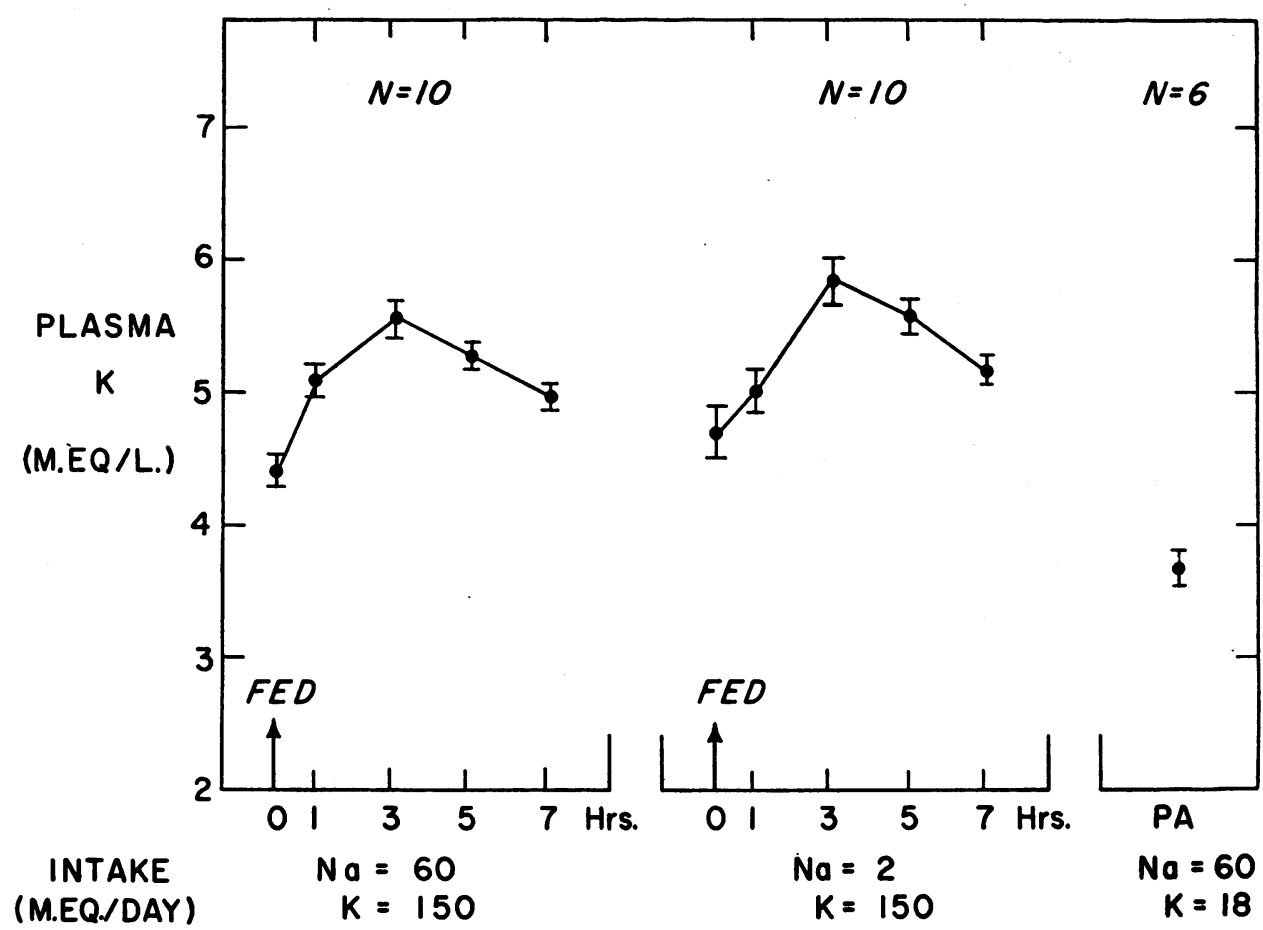

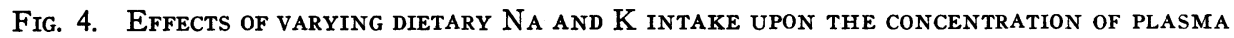
$\mathrm{K}$. PA is the abbreviation for "postabsorptive." Mean values and standard errors are presented.

aldosterone production. In contrast, in dogs 4,5 , and 7 , aldosterone secretion fell after nephrectomy but not to the control level ; corticosterone production did, however, return to the control level in these three dogs. Nephrectomy had no influence on the concentration of plasma $\mathrm{Na}$, which remained at the normal level.

Steroid secretion during infusion of potassium salts into the arterial supply of isolated adrenals. This experiment was performed to examine the possibility of a direct action of the $\mathrm{K}$ ion on the adrenal cortex. The results of a typical experiment are presented in Figure 2. Both $\mathrm{KCl}$ and $\mathrm{K}_{2} \mathrm{SO}_{4}$ produced an increase in aldosterone secretion (Figure 3). For each group of experiments the change is significant at the $2 \%$ level. If all 16 experiments of the two groups are combined, the increment in aldosterone secretion is highly significant $(p<.01)$. Corticosterone secretion increased in only two of the experiments with the $\mathrm{KCl}$ infusion. Infusion of normal saline alone was without effect on steroid secretion.

Effects of a high potassium intake on the concentration of plasma $K$. To determine the possible physiological significance of a high plasma level of $\mathrm{K}$, the influence of a high $\mathrm{K}$ diet on plasma $\mathrm{K}$ concentration was studied both in the presence of a normal $\mathrm{Na}$ intake and in the presence of a low $\mathrm{Na}$ intake. The results are presented in Figure 4. The postabsorptive level of plasma $\mathrm{K}$ was slightly elevated in both high $\mathrm{K}$ groups in comparison with the postabsorptive plasma $\mathrm{K}$ concentration during a $\mathrm{K}$ intake of $18 \mathrm{mEq}$ per day and a $\mathrm{Na}$ intake of $60 \mathrm{mEq}$ per day. A further increase in plasma $\mathrm{K}$ occurred after ingestion of the high $\mathrm{K}$ diet. The peak of the response was observed 3 hours postprandially. The response on the low $\mathrm{Na}$ diet was not significantly different from the effect observed on a $\mathrm{Na}$ intake of $60 \mathrm{mEq}$ per day. These data show that the plasma $\mathrm{K}$ concentration during a high $\mathrm{K}$ intake was increased to levels as high as those frequently observed to enhance steroid secretion during the intravenous infusion of $\mathrm{K}$.

Relation of a high $K$ intake to the concentration of plasma $K$ and to aldosterone excretion. On the basis of the previous experiment. studies were conducted on the effects of a normal $\mathrm{Na}$ and a 
high $\mathrm{K}$ diet and of a low $\mathrm{Na}$ and a high $\mathrm{K}$ diet on urinary aldosterone excretion. The results are presented in Figure 5 and Table II. An increase in urinary aldosterone excretion occurred in association with the increase in plasma $\mathrm{K}$ following the meal. The effect was observed during a high $\mathrm{K}$ intake with both a normal and a low $\mathrm{Na}$ diet. No further augmentation in aldosterone production by $\mathrm{K}$ was detected by changing from a normal to a low $\mathrm{Na}$ intake. The shift in $\mathrm{K}$ intake from 18 to $150 \mathrm{mEq}$ per day did not alter $\mathrm{Na}$ balance (Figure 5).

Aldosterone secretion during infusion of isolated adrenals with a 5\% aqueous solution of glucose or with 5\% glucose in normal saline. Infusion of a $5 \%$ aqueous solution of glucose into the arterial supply of isolated adrenals lowered the concentration of $\mathrm{Na}$ in the perfusing blood. During infusion of $5 \%$ glucose in water, aldosterone secretion increased from .008 to .018 $\mu \mathrm{g}$ per minute $(\mathrm{n}=15 ; \mathrm{p}<.01)$ in association with a fall in plasma $\mathrm{Na}$ concentration from 146 to $126 \mathrm{mEq}$ per $\mathrm{L}$ (Figure 6). The smallest decrease in plasma $\mathrm{Na}$ in which a definite elevation in aldosterone production occurred was $14 \mathrm{mEq}$ per L. The plasma $\mathrm{K}$ level fell from 3.5 to 3.2 $m E q$ per $\mathrm{L}(\mathrm{n}=15 ; \mathrm{p}<.02)$. For the group of 15 experiments, corticosterone secretion was un-

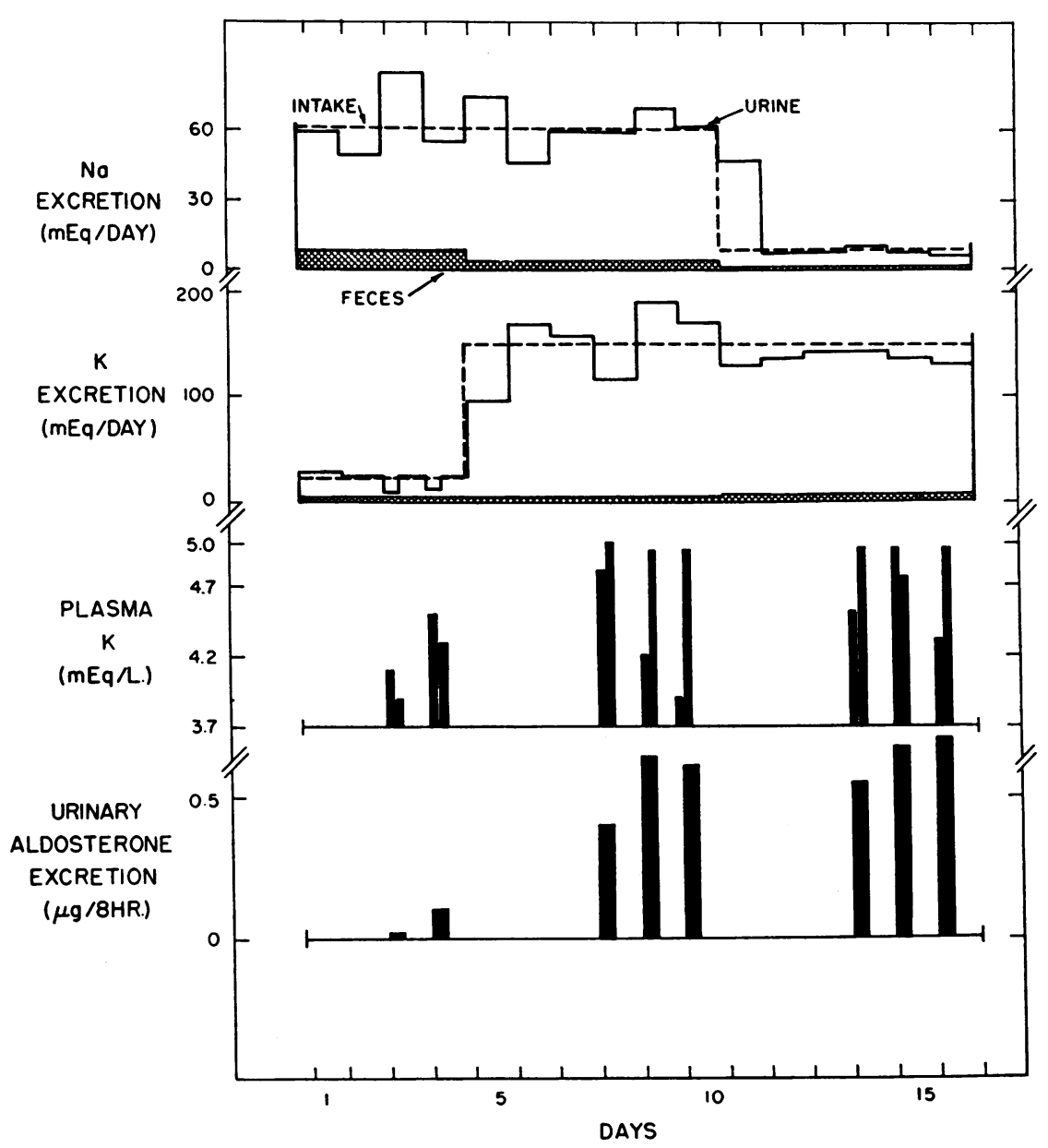

Fig. 5. EfFects of a high K intake during a normal and a low Na diet upon THE PLASMA K CONCENTRATION AND URINARY aldosterone exCretion. The tivo values for plasma $\mathrm{K}$ were obtained immediately before feeding and 3 to 4 hours postprandially, which is the time of the peak postprandial rise in the concentration of plasma K. Urinary aldosterone excretion was measured during the 8-hour period following the meal because the plasma $\mathrm{K}$ level was highest during this period. 
TABLE II

Relation of a high $K$ intake and plasma $K$ to urinary aldosterone excretion

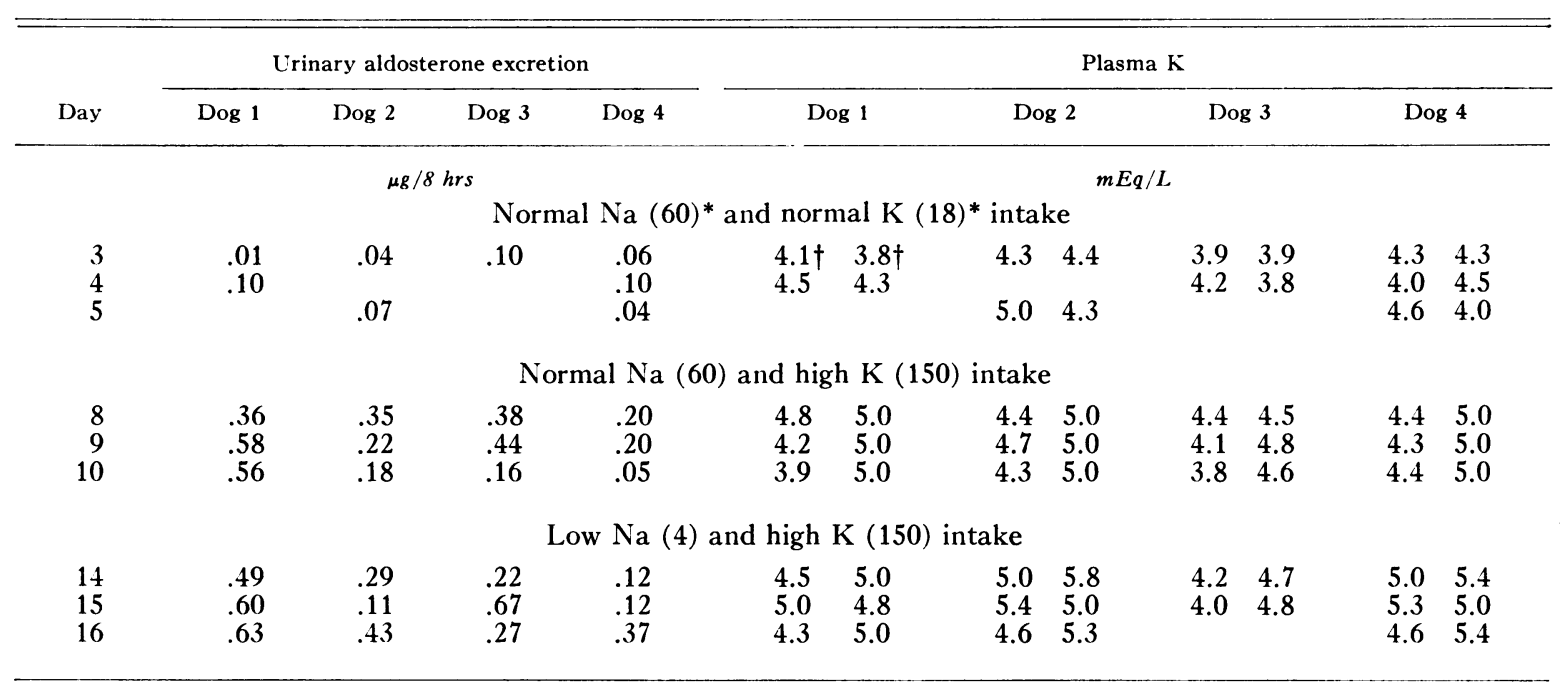

* Electrolyte intake is expressed in milliequivalents per day.

$\dagger$ For each dog the values of plasma $K$ concentration on the left are postabsorptive values, while postprandial values are presented on the right.

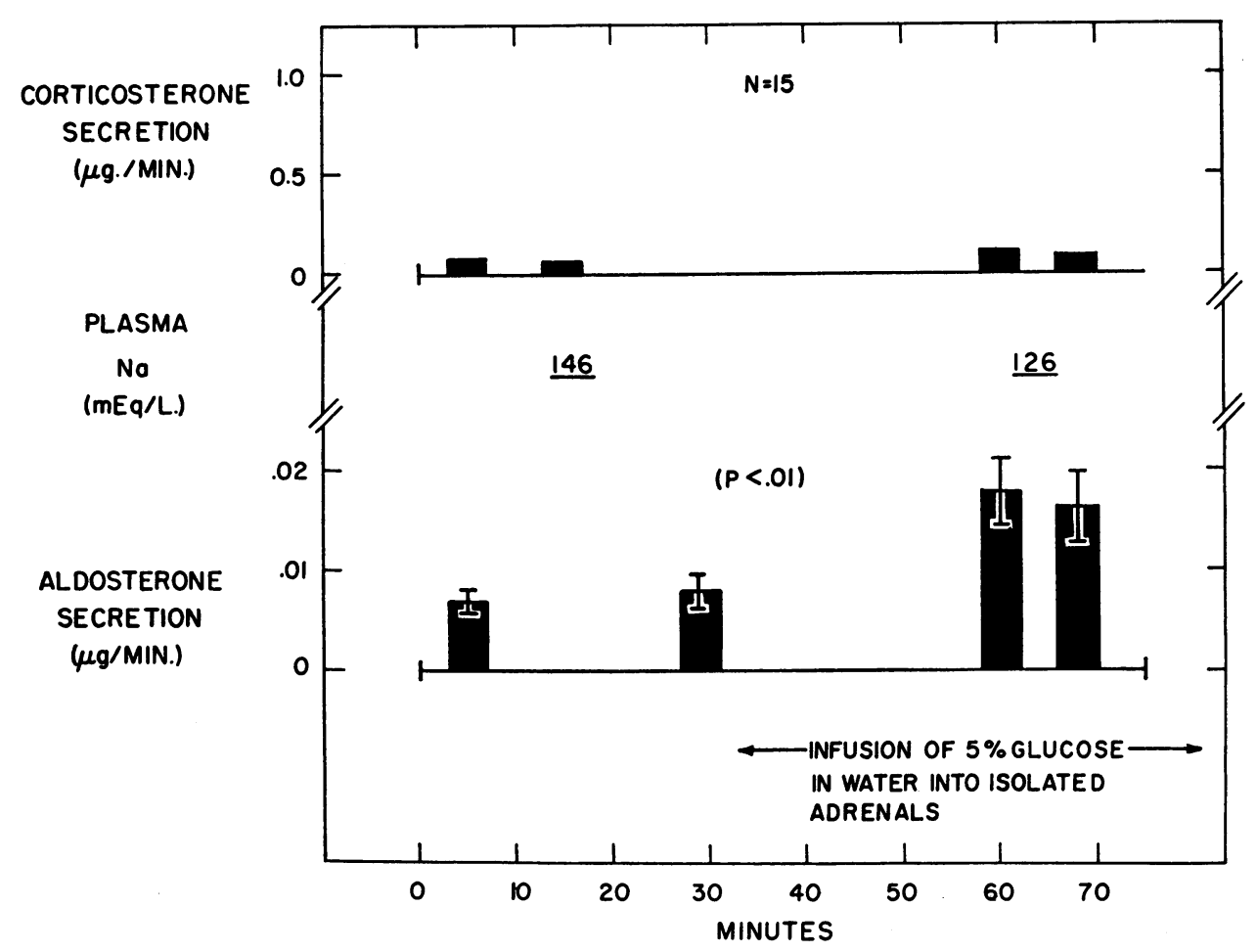

Fig. 6. EFFects of infusion of 5\% AQUEOUS SOLUtion OF GLUCOSE INTO THE ARTERY SUPPLy OF ISOLATED ADRENALS OF 15 HYPOPHYSECTOMIZED-NEPHRECTOMIZED DOGS. Mean values and standard errors are presented for aldosterone secretion. 
altered; however, in 2 of the 15 experiments the two values of corticosterone secretion during infusion of glucose were unequivocally higher than the two control values. As a control study, 5\% glucose in normal saline was studied in 8 experiments, but no effect on aldosterone or corticosterone secretion occurred (for aldosterone secretion $\mathrm{p}>0.7)$.

\section{DISCUSSION}

It is clear that alterations in $\mathrm{Na}$ intake influence the rate of secretion of aldosterone (1-9). These effects of $\mathrm{Na}$ appear to be mediated by the reninangiotensin system $(8,21)$. Attempts to relate a decrease in the concentration of plasma $\mathrm{Na}$ to aldosterone production have been unsuccessful with two exceptions. In the early studies of Denton and associates in sheep (5), they found that a low $\mathrm{Na}$ concentration in association with an increase in the plasma $\mathrm{K}$ level increased aldosterone output, while neither a low plasma $\mathrm{Na}$ nor a high plasma $\mathrm{K}$ concentration alone influenced aldosterone secretion. More recently, the Australian workers (6) have presented data from individual experiments in sheep which suggest that either a low plasma or a high plasma $\mathrm{K}$ increases aldosterone secretion. The combined ionic alteration appears to be more effective than the change in either ion alone. Also, Rosenfeld and associates (22) reported that a low $\mathrm{Na}$ and a high $\mathrm{K}$ concentration augmented aldosterone output in perfused beef adrenals, but the alterations of $\mathrm{Na}$ and $\mathrm{K}$ were too marked for the results to have physiological significance.

The present experiments show that lowering the local plasma $\mathrm{Na}$ concentration to 120 to $130 \mathrm{mEq}$ per $\mathrm{L}$ by direct arterial infusion of isolated adrenals with $5 \%$ glucose in water was associated with an increase in aldosterone secretion. This finding suggests the possibility that the $\mathrm{Na}$ ion per se influenced aldosterone secretion, but this cannot be stated with certainty because the concentration of other plasma constituents was lowered. Failure of investigators $(3,23)$ to find an elevation in urinary aldosterone excretion in human subjects with hyponatremia secondary to Pitressin and water loading is probably attributable to the marked expension of body fluid volume which decreased aldosterone output by the renin-angiotensin system.
In regard to the role of $\mathrm{K}$ in the regulation of aldosterone secretion, the various reports have yielded conflicting results with considerable divergence of opinion. The early studies were concerned with the urinary excretion of aldosterone during use of insensitive methods for analysis of the hormone, and these methods limited the amounts which could be detected. Since the changes in aldosterone excretion in urine even with marked alterations in plasma $\mathrm{K}$ are not large. small changes may not have been detected in some of the early studies. Laragh and Stoerk (10) observed an increase in urinary aldosterone output with $\mathrm{K}$ loading in the presence of a low $\mathrm{Na}$ intake, while others $(2,3)$ reported hyperaldosteronuria secondary to $\mathrm{K}$ loading with a normal $\mathrm{Na}$ intake. The finding of Hernando and associates (4) that urinary aldosterone output failed to increase during $\mathrm{K}$ loading in association with a low $\mathrm{Na}$ intake remains unexplained.

Certain studies of steroid production during $\mathrm{K}$ administration to normal dogs stressed by laparotomy were complicated by the large amounts of circulating ACTH which obscured the effects produced by infusion of $\mathrm{K}(7,11,12)$. Nevertheless. Moran and coworkers (11) obtained suggestive evidence that intravenous infusion of $\mathrm{KCl}$ augmented aldosterone secretion in laparotomized intact dogs. In contrast, Gann and co-workers (12) were unable to detect an increase in aldosterone production during intravenous infusion of $\mathrm{KCl}$ into laparotomized intact dogs, but reported that intracarotid arterial infusion of large quantities of $\mathrm{KCl}$ augmented aldosterone secretion in this preparation. Also, Rosnagle and Farrell (7) failed to find an increase in aldosterone secretion after $\mathrm{K}$ loading, and they suggested that the increased urinary output of aldosterone observed by others was secondary to altered renal handling of the hormone.

The present experiments demonstrate that an increase in aldosterone secretion occurred in association with an elevation in the concentration of plasma $\mathrm{K}$ in hypophysectomized dogs. Marked increments in aldosterone production were observed during very high levels of plasma $\mathrm{K}$. but a definite increase in aldosterone output occurred with elevations in plasma $\mathrm{K}$ concentration as small as $1.3 \mathrm{mEq}$ per $\mathrm{L}$. Since the response occurred 
during infusion of either $\mathrm{KCl}$ of $\mathrm{K}_{2} \mathrm{SO}_{4}$, the data indicate that the $\mathrm{K}$ ion produced the effect.

In three animals, the high rate of aldosterone secretion secondary to hyperkalemia continued after removal of the kidneys, which demonstrates that increased secretion of renin is unnecessary for the response. It seems unlikely that insufficient time was allowed for the effects of nephrectomy to be manifest, since previous studies $(8,14)$ have demonstrated a striking fall in aldosterone secretion within 30 minutes to 1 hour following nephrectomy. In the other three animals, aldosterone output declined after nephrectomy but not to the control level. This decline suggests that the renin-angiotensin system was contributing to the level of aldosterone production in these animals. It should be pointed out that the concentration of plasma $\mathrm{K}$ is not increased by angiotensin II $(24,25)$.

Since an increase in aldosterone secretion occurred in response to an elevation in the level of plasma $\mathrm{K}$ in the absence of both the anterior pituitary and the kidneys, a direct influence of the $\mathrm{K}$ ion on the adrenal cortex was suggested. To test this possibility, very small amounts ( 15 to $18 \mu \mathrm{Eq}$ per minute) of $\mathrm{K}$ were infused into the arterial supply of isolated adrenals. This rate of infusion of $\mathrm{K}$ was considerably less than the rate of peripheral infusion of $\mathrm{KCl}$ or $\mathrm{K}_{2} \mathrm{SO}_{4}$ of 550 to $1,140 \mu \mathrm{Eq}$ per minute used to elevate the peripheral plasma $\mathrm{K}$ concentration. Direct infusion of either $\mathrm{KCl}$ or $\mathrm{K}_{2} \mathrm{SO}_{4}$ into isolated adrenals produced an increase in aldosterone output which demonstrates a direct action of the $\mathrm{K}$ ion on the adrenal cortex.

The response in aldosterone secretion to $\mathrm{K}$ salts in the isolated adrenal preparation of hypophysectomized-nephrectomized dogs (Figure 3) was less than in the in situ adrenal of hypophysectomized animals (Table I). This was probably attributable to a decrease in sensitivity of the isolated adrenals because responses to angiotensin II in these isolated adrenals varied considerably, and in some preparations the response was negligible. This low sensitivity may be related to interference with the adrenal arterial supply that resulted during isolation of the adrenals.

The observation that aldosterone production was augmented by small increments in plasma $K$ suggests that the $\mathrm{K}$ ion might play a role in the normal regulation of aldosterone secretion. To evaluate a possible physiological role of $\mathrm{K}$, the influence of a diet high in $\mathrm{K}$ ( 8 times the $\mathrm{K}$ intake in the synthetic diet that is routinely used in our laboratory) on the plasma $\mathrm{K}$ concentration was studied. In changing $\mathrm{K}$ intake from 18 to 150 $\mathrm{mEq}$ per day, the postabsorptive level of plasma $\mathrm{K}$ increased from 3.7 to $4.4 \mathrm{mEq}$ per L. Postprandial measurements revealed a further increase in plasma $\mathrm{K}$ from 4.4 to $5.5 \mathrm{mEq}$ per $\mathrm{L}$. This increase in plasma $\mathrm{K}$ from 3.7 to $5.5 \mathrm{mEq}$ per $\mathrm{L}$ is slightly greater than the lowest increments observed to increase aldosterone secretion in acute experiments. These results agree with the earlier finding of Laragh and Capeci (26) that an increase in plasma $\mathrm{K}$ of 1.2 to $1.6 \mathrm{mEq}$ per $\mathrm{L}$ occurred secondary to ingestion of $80 \mathrm{mEq}$ of $\mathrm{KCl}$ in dogs. In the present study, no significant difference in the increment in plasma $\mathrm{K}$ produced by a high $\mathrm{K}$ diet was observed during a normal and a low $\mathrm{Na}$ intake. This finding confirms the observation (26) that plasma $\mathrm{K}$ increased to essentially the same extent during $\mathrm{KCl}$ administration to dogs on a normal and a low $\mathrm{Na}$ intake. However, $\mathrm{Na}$ depletion markedly augmented the increase in plasma $K$ following $K$ loading (26). It appears, therefore, that under physiological conditions such as following the ingestion of a large quantity of meat, the elevation in plasma $\mathrm{K}$ might be sufficient to increase the production of aldosterone.

To examine further the possible influence of a high $\mathrm{K}$ intake on aldosterone production, the rate of urinary aldosterone excretion was measured during a normal $\mathrm{Na}$ and $\mathrm{K}$ intake, during a normal $\mathrm{Na}$ and a high $\mathrm{K}$ diet, and during a low $\mathrm{Na}$ and a high $\mathrm{K}$ intake. Laragh and Stoerk (10) reported that a low $\mathrm{Na}$ and high $\mathrm{K}$ intake increased aldosterone output in urine, but they were unable to detect a response during $\mathrm{K}$ loading when $\mathrm{Na}$ intake was normal. In the present experiments, urinary aldosterone output was increased during a high $\mathrm{K}$ diet regardless of the $\mathrm{Na}$ intake. The increment in aldosterone excretion was associated with hyperkalemia. Also, the effect was not due to loss of $\mathrm{Na}$, since the high $\mathrm{K}$ diet did not produce a negative $\mathrm{Na}$ balance. Laragh and Capeci (26) also observed no appreciable change in $\mathrm{Na}$ excretion during $\mathrm{KCl}$ administration to dogs. These results may reflect a difference in 
the response of dog and man to $\mathrm{K}$ administration, since several observers $(2,3,27)$ have reported a natriuresis during $\mathrm{K}$ administration to human subjects.

The importance of a low $\mathrm{Na}$ and a high $\mathrm{K}$ concentration in plasma on aldosterone secretion in sheep has been emphasized by Denton and coworkers $(5,6)$. Since the sheep is a herbivore and ingests large quantities of $\mathrm{K}$, the question arises as to whether the role of $\mathrm{K}$ is more important in herbivorous than in carnivorous animals and man. Additional studies are needed to evaluate the importance of $\mathrm{K}$ in the control of aldosterone secretion in animals which normally ingest large quantities of $\mathrm{K}$. Another interesting unanswered question is the role of aldosterone in the regulation of $\mathrm{K}$ excretion during ingestion of large amounts of $\mathrm{K}$.

Finally, the role of plasma electrolyte changes in the control of aldosterone secretion in experimental and in clinical states with secondary hyperaldosteronism must be considered. In studies of the effects of acute caval constriction (16), marked increments in aldosterone secretion were observed before plasma $\mathrm{K}$ increased or in the absence of hyperkalemia; plasma $\mathrm{Na}$ was usually normal. In dogs with hyperaldosteronism secondary to chronic thoracic caval constriction or chronic experimental heart failure, the concentration of plasma $\mathrm{K}$ was frequently normal (28). In patients with cirrhosis of the liver and edema, Eisenmenger, Blondheim, Bongiovanni, and Kunkel (29) found that the plasma $\mathrm{K}$ concentration was elevated in only 1 of 7 patients. Birkenfeld, Leibman, O'Meara, and Edelman (30) obtained similar results in a larger series of patients with cirrhosis and edema; of 16 male patients, only one showed a plasma $\mathrm{K}$ concentration above $5.0 \mathrm{mEq}$ per $\mathrm{L}$ and the plasma $\mathrm{K}$ concentration was normal in 5 female patients. Similarly, these workers (30) found levels of plasma $\mathrm{K}$ above $5.0 \mathrm{mEq}$ per $\mathrm{L}$ in only 2 of 16 patients with congestive heart failure and edema. The average value reported by Birkenfeld and associaties (30) for the plasma $\mathrm{K}$ concentration in ten hospitalized control subjects was $4.5 \mathrm{mEq}$ per $\mathrm{L}$. Two of these patients showed plasma $\mathrm{K}$ concentrations above $5.0 \mathrm{mEq}$ per $\mathrm{L}$. It is clear, therefore, that an elevation of plasma $\mathrm{K}$ in clinical states with edema is an unusual finding. Also, it is well-known that the con- centration of plasma $\mathrm{Na}$ is usually normal in heart failure and in cirrhosis of the liver. These results exclude a primary role for either hyperkalemia or hyponatremia in the pathogenesis of secondary hyperaldosteronism. Current evidence (8, $13,14,21,31-35)$ strongly favors the view that the renin-angiotensin system is the primary mechanism for hypersecretion of aldosterone in clinical states with secondary hyperaldosteronism.

\section{SUM MARY}

1. Intravenous infusion of $\mathrm{KCl}$ or $\mathrm{K}_{2} \mathrm{SO}_{4}$ augmented the rates of aldosterone and corticosterone secretion in hypophysectomized dogs. The response was observed with an increment in plasma $\mathrm{K}$ as small as $1.3 \mathrm{mEq}$ per $\mathrm{L}$. Porter-Silber chromogen output was also increased in the two dogs with the largest increments in corticosterone production. Subsequent nephrectomy failed to block the response in aldosterone and corticosterone secretion to hyperkalemia in some animals, and in others the secretion of both steroids fell following nephrectomy.

2. Infusion of $\mathrm{KCl}$ or $\mathrm{K}_{2} \mathrm{SO}_{4}$ into the arterial supply of isolated adrenals increased aldosterone secretion. This finding provided evidence for a direct effect of the $\mathrm{K}$ ion on the adrenal cortex.

3. In normal, intact dogs, a high $\mathrm{K}$ diet resulted in an increase in plasma $\mathrm{K}$ equivalent to the hyperkalemia that augmented aldosterone secretion during intravenous infusion of $\mathrm{K}$. Under these circumstances urinary aldosterone excretion was elevated in association with the peak of the postprandial response in plasma $K$ to the dietary $K$ load.

4. Infusion of $5 \%$ glucose in water into the arterial supply of isolated adrenals produced a reduction in plasma $\mathrm{Na}$ and an increase in aldosterone secretion.

\section{REFERENCES}

1. Luetscher, J. A., Jr., and B. J. Axelrad. Increased aldosterone output during sodium deprivation in normal men. Proc. Soc. exp. Biol. (N. Y.) 1954, 87, 650 .

2. Luetscher, J. A., Jr., and R. H. Curtis. Aldosterone: observations on the regulation of sodium and potassium balance. Ann. intern. Med. 1955, 43, 658. 
3. Bartter, F. C., I. H. Mills, E. G. Biglieri, and C. Delea. Studies on the control and physiologic action of aldosterone. Recent Progr. Hormone Res. 1959, 15, 311.

4. Hernando, L., J. Crabbe, E. J. Ross, W. J. Reddy, A. E. Renold, D. H. Nelson, and G. W. Thorn. Clinical experience with a physico-chemical method for estimation of aldosterone in urine. Metabolism 1957, 6, 518.

5. Denton, D. A., J. R. Goding, and R. D. Wright. Control of adrenal secretion of electrolyte-active steroids. Adrenal stimulation by cross-circulation experiments in conscious sleep. Brit. Med. J. 1959, 2, 522.

6. Blair-West, J. R., J. P. Coghlan, D. A. Denton, J. R. Goding, J. A. Munro, R. E. Peterson, and M. Wintour. Humoral stimulation of adrenal cortical secretion. J. clin. Invest. 1962, 41, 1606.

7. Rosnagle, R. S., and G. L. Farrell. Alterations in electrolyte intake and adrenal steroid secretion. Amer. J. Physiol. 1956, 187, 7.

8. Davis, J. O., C. R. Ayers, and C. C. J. Carpenter. Renal origin of an aldosterone-stimulating hormone in dogs with thoracic caval constriction and in sodium-depleted dogs. J. clin. Invest. 1961, 40, 1466.

9. Singer, B., and M. P. Stack-Dunne. The secretion of aldosterone and corticosterone by the rat adrenal. J. Endocr. 1955, 12, 130.

10. Laragh, J. H., and H. C. Stoerk. A study of the mechanism of secretion of the sodium-retaining hormone (aldosterone). J. clin. Invest. 1957, 36, 383.

11. Moran, W. H., Jr., J. C. Rosenberg, and B. Zimmermann. The regulation of aldosterone output: significance of potassium ion. Surg. Forum 1959, 9, 120.

12. Gann, D. S., J. F. Cruz, A. G. T. Casper, and F. C. Bartter. Mechanism by which potassium increases aldosterone secretion in the dog. Amer. J. Physiol. 1962, 202, 991.

13. Davis, J. O. Mechanisms regulating the secretion and metabolism of aldosterone in experimental secondary hyperaldosteronism. Recent Progr. Hormone Res. 1961, 17, 293.

14. Davis, J. O., C. C. J. Carpenter, C. R. Ayers, J. E. Holman, and R. C. Bahn. Evidence for secretion of an aldosterone-stimulating hormone by the kidney. J. clin. Invest. 1961, 40, 684.

15. Davis, J. O., R. C. Bahn, M. J. Goodkind, and W. C. Ball, Jr. Aldosterone excretion in urine from hypophysectomized dogs with thoracic inferior vena cava constriction. Amer. J. Physiol. 1957, 191, 329.

16. Davis, J. O., B. Kliman, N. A. Yankopoulos, and R. E. Peterson. Increased aldosterone secretion following acute constriction of the inferior vena cava. J. clin. Invest. 1958, 37, 1783.
17. Hilton, J. G., D. C. Weaver, G. Muelheims, V. V. Glaviano, and R. Wégria. Perfusion of the isolated adrenals in situ. Amer. J. Physiol. 1958, 192, 525.

18. Kliman, B., and R. E. Peterson. Double isotope derivative assay of aldosterone in biological extracts. J. biol. Chem. 1960, 235, 1639.

19. Davis, J. O., C. C. J. Carpenter, C. R. Ayers, and R. C. Bahn. Relation of anterior pituitary function to aldosterone and corticosterone secretion in conscious dogs. Amer. J. Physiol. 1960, 199, 212.

20. Peterson, R. E., A. Karrer, and S. L. Guerra. Evaluation of Silber-Porter procedure for determination of plasma hydrocortisone. Analyt. Chem. 1957, 29, 144.

21. Davis, J. O., P. M. Hartroft, E. O. Titus, C. C. J. Carpenter, C. R. Ayers, and H. E. Spiegel. The role of the renin-angiotensin system in the control of aldosterone secretion. J. clin. Invest. 1962, 41, 378.

22. Rosenfeld, G., E. Rosemberg, F. Lngar, and R. I. Dorfman. Regulation of the secretion of aldosterone-like material. Endocrinology 1956, 58, 255.

23. Beck, J. C., I. Dyrenfurth, C. Giroud, and E. H. Venning. Observations on the regulatory mechanisms of aldosterone secretion in man. Arch. intern. Med. 1955, 96, 463.

24. Finnerty, F. A., Jr., G. D. Massaro, V. Chupkovich, and J. Tuckman. Evaluation of the pressor, cardiac, and renal hemodynamic properties of angiotensin II in man. Circulat. Res. 1961, 9, 256.

25. Davis, J. O., J. Urquhart, and J. T. Higgins, Jr. Unpublished observations.

26. Laragh, J. H., and N. E. Capeci. Effect of administration of potassium chloride on serum sodium and potassium concentration. Amer. J. Physiol. 1955, 180, 539.

27. Liddle, G. W., L. L. Bennett, and P. H. Forsham. The prevention of ACTH-induced sodium retention by the use of potassium salts: a quantitative study. J. clin. Invest. 1953, 32, 1197.

28. Yankopoulos, N. A., J. O. Davis, E. Cotlove, and M. Trapasso. Mechanism of myocardial edema in dogs with chronic congestive heart failure. Amer. J. Physiol. 1960, 199, 603.

29. Eisenmenger, W. J., S. H. Blondheim, A. M. Bongiovanni, and $H$. G. Kunkel. Electrolyte studies on patients with cirrhosis of the liver. J. clin. Invest. 1950, 29, 1491.

30. Birkenfeld, L. W., J. Leibman, M. P. O'Meara, and I. S. Edelman. Total exchangeable sodium, total exchangeable potassium and total body water in edematous patients with cirrhosis of the liver and congestive heart failure. J. clin. Invest. 1958, 37, 687.

31. Davis, J. O. The control of aldosterone secretion. Physiologist 1962, 5, 65. 
32. Davis, J. O., C. C. J. Carpenter, and C. R. Ayers. Relation of renin and angiotensin II to the control of aldosterone secretion. Circulat. Res. 1962, 11, 171.

33. Davis, J. O. Adrenocortical and renal hormonal function in experimental cardiac failure. Circulation 1962, 25, 1002.
34. Mulrow, P. J., and W. F. Ganong. Role of the kidney and the renin-angiotensin system in the response of aldosterone secretion to hemorrhage. Circulation 1962, 25, 213.

35. Ganong, W. F., and P. J. Mulrow. Evidence of secretion of an aldosterone-stimulating substance by the kidney. Nature (Lond.) 1961, 190, 1115. 